\title{
Penerapan Metode Simulasi Untuk Membantu Siswa Dalam Melaksanakan Shalat Fardu Lima Waktu Dengan Baik dan Benar di Kelas VII B MTs NW Karang Baru
}

\author{
${ }^{1}$ Lina Mardiana, ${ }^{2}$ Muhammad Sabri \\ ${ }^{1}$ linamardianaro1o2@gmail.com, ${ }^{2}$ shabri12494@gmail.com \\ 1, 2 Manajemen pendidika Islam, STAI Darul Kamal NW Kembang Kerang NTB
}

\begin{abstract}
Abstrak
Materi shalat fardu merupakan salah satu materi yang sangat urgen sekali dalam Kurikulum Pendidikan Agama Islam yang harus tercapai secara tuntas kepada 3 ranah yaitu kognitif, afektif dan psikomotorik. Agar tercapainya 3 ranah tersebut maka haruslah menggunakan metode yang tepat dalam proses pembelajaran dan harus disesuaikan dengan kondisi lingkungan sekitar. Masih Banyaknya siswa-siswi kelas VII B MTs Nahdlatul Wathan Karang Baru yang belum bisa melaksanakan shalat fardu dengan baik dan benar. Jika dibiarkan berlarut-larut maka siswa-siswi tidak akan pernah mengetahui tata cara sholat yang baik dan benar, Untuk mengatasi masalah ini, peneliti tertarik menggunakan metode simulasi untuk membantu siswa dalam melaksanakannya. Maka dari itu peneliti mengangkat judul penerapan metode simulasi untuk membantu siswa dalam melaksanakan sholat fardu lima waktu dengan baik dan benar. Hasil dari penelitian menunjukan bahwa pada siklus I ketercapaian daya serap siswa mencapai 66,9\% dari 24 siswa dan tingkat ketuntasan klasikal siswa dalam simulasi sholat lima waktu hanya mencapai $32,5 \%$ atau hanya 11 siswa saja. sedangkan pada siklus II ketercapaian daya serap siswa mencapai 73,7\% tingkat ketuntasan klasikal siswa dalam mensimulasi sholat lima waktu mencapai $71, \%$ atau 23 siswa. Pada mata pelajaran fikih pada kompetensi ini sudah meningkat walaupun belum mencapai $99,9 \%$. Perubahan yang terjadi dari siklus I ke siklus II menunjukkan bahwa menggunakan metode simulasi sudah efektif dilakukan.
\end{abstract}

Kata Kunci: Metode Simulasi, Sholat Fardu

\section{Pendahuluan}

Pelajaran ilmu fikih merupakan suatu didiplin ilmu agama Islam yang menyangkut perbuatan sehari-hari. Rosyada mengatakan pengertian Fiqih ialah mengetahui hukum-hukum Syara' yang bersifat amaliah yang di kaji dari dalil-dalilnya yang terinci. ${ }^{1}$ Ilmu ini sangat penting sekali karena dipergunakan dalam kehidupan sehari hari terutama yang menyangkut masalah amaliyah seperti, shalat, zakat, puasa dan ibadah-ibadah lainnya.Salah satu amaliyah yang dibahas dalam ilmu fikih adalah shalat fardu. Shalat merupakan salah satu pondasi agama Islam dan amalan pertama

\footnotetext{
${ }^{1}$ http://www.pengertianpakar.com/2014/09/pengertian-fiqih-menurut-para-pakar
} 
yang akan dihitung dihari kiamat sebagaimana yang sudah dijelaskan oleh Rasulullah SAW.

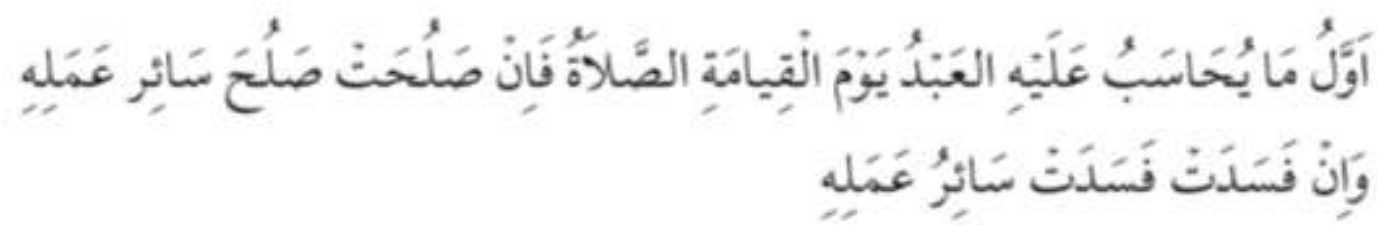

Amalan yang pertama kali akan dihisab bagi seorang hamba pada hari kiamat adalah salat. Jika salatnya baik, maka akan dinilai baik semua amalnya yang lain dan jika salatnya rusak maka akan dinilai jeleklah semua amalnya yang lain". (H.R. Imam Tabrani) ${ }^{2}$

Salat secara bahasa berarti doa. Secara istilah salat adalah ibadah yang terdiri dari perkataan dan perbuatan tertentu, yang dimulai dengan takbir, dan diakhiri dengan salam. Salat wajib juga disebut juga dengan salat fardu atau salat maktubah yang berarti salat yang harus dikerjakan orang Islam yang telah memenuhi syarat. Salat wajib dibagi menjadi dua macam, yaitu salat fardu `ain (seluruh umat islam wajib menjalankannya) dan salat wajib fardhu kifayah (apabila salah seorang telah melaksanakan, maka gugurlah kewajiban bagi yang lainnya).Dasar diwajibkannya shalat fardu adalah firman Allah SWT yaitu “Dan dirikanlah salat dan bayarkanlah zakat, dan ruku'lah bersama orang-orang yang ruku'" (QS. al-Baqara 2:43) ${ }^{3}$.

Materi shalat fardu merupakan salah satu materi yang sangat urgen sekali dalam Kurikulum Pendidikan Agama Islam yang harus tercapai secara tuntas kepada 3 ranah yaitu kognitif, afektif dan psikomotorik. Agar tercapainya 3 ranah tersebut maka haruslah menggunakan metode yang tepat dalam proses pembelajaran dan harus disesuaikan dengan kondisi lingkungan sekitar .Peneliti selaku guru fikih selalu memberikan bimbingan kepada siswa agar bisa melaksanakan shalat fardu lima waktu dengan baik dan benar. Upaya peneliti antara lain : menyiapkan RPP, silabus, menyiapkan modul. Namun, kenyataannya masih banyak siswa-siswi kelas VII B MTs

\footnotetext{
2 Kementrian Agama Republik Indonesia. buku fikih siswa VII. (Jakarta, 2014)

${ }^{3}$ Kementrian Agama Republik Indonesia. Al-qur'an dan terjemehannya.
} 
Nahdlatul Wathan Karang Baru. yang belum bisa melaksanakan shalat fardu dengan baik dan benar.

Kalau masalah ini dibiarkan berlarut-larut maka siswa-siswi tidak akan pernah tahu tentang tata cara sholat fardu yang baik dan benar. Untuk mengatasi masalah ini, peneliti tertarik menggunakan metode simulasi. metode simulasi adalah menampilkan simbol-simbol peralatan yang menggantikan proses, kejadian, atau benda yang sebenarnya. ${ }^{4}$ Metode simulasi adalah cuplikan suatu situasi kehidupan nyata yang diangkat ke dalam kegiatan pembelajaran. ${ }^{5}$ Law dan Kleton (1991) mendefinisikan simulasi adalah Sekumpulan metode dan aplikasi untuk menirukan atau merepresentasikan perilaku dari suatu sistem nyata, yang biasanya dilakukan pada komputer dengan perangkat lunak tertentu. ${ }^{6}$

Berdasarkan latar belakang masalah di atas. Maka, saya sebagai guru fikih termotivasi untuk melaksanakan penelitian tindakan kelas (PTK) dengan judul "penerapan metode simulasi untuk membantu siswa dalam melaksanakan shalat fardu lima waktu dengan baik dan benar di kelas vii b mts nw karang baru"

\section{Metode Penelitian}

Penelitian yang digunakan penulis adalah Penelitian Tindakan Kelas (PTK) atau yang disebut dengan istilah Classroom Action Research ${ }^{7}$. Dengan menggukan metode simulasi. Upaya yang dilakukan untuk memperoleh data yang valid dan reliabel adalah dengan menggunakan sumber-sumber yang sesuai dan bisa dipercaya kebenarannya serta berdasarkan metode yang sesuai. Sehubungan dengan pengumpulan data ini, penulis menggunakan sumber data yaitu berupa riset lapangan. Riset lapangan tersebut merupakan aktivitas penulis dalam mengadakan penulisan ini, untuk memperoleh data-data empiris yang diperlukan dalam rangka pemenuhan informasi dan data-data yang diperlukan ${ }^{8}$ Selanjutnya tehnik pengumpulan data yang penaliti gunakan adalah

\footnotetext{
${ }^{4}$ Martinis Yamin, Strategi Pembelajaran Berbasis Kompetensi, (Jakarta: Gaung Persada Press, 2007)

${ }^{5}$ Sudjana S. Metode Teknik Pembelajaran Partisipatif, (Bandung: Falah Production, 2001)

6 http:/ /www.infodanpengertian.com/2016/02/pengertian-simulasi-menurut-para-ahli

${ }^{7}$ Suharsimi Arikunto. Prosedur Penelitian Suatu Pendekatan Praktik. (Jakarta: Rineka Cipta, 2013)

${ }^{8}$ E. Mulyasa, Praktik Penelitian Tindakan Kelas. (Bandung: PT. Remaja Rosdakarya, 2009)
} 
Metode observasi, dan dokumentasi. Metode observasi digunakan penulis untuk mendapatkan data tentang penerapan metode simulasi untuk membantu siswa dalam melaksanakan shalat fardu lima waktu dengan baik dan benar di kelas VII B Mts Nw Karang Baru yaitu dengan cara penulis ikut berpartisipasi langsung dalam mengamati dan mencatat materi yang diteliti di tempat penulisan tersebut. Sedangkan metode dokumentasi digunakan oleh penulis untuk mendukung penelitian tindakan kelas (PTK) tentang metode simulasi untuk membantu siswa dalam melaksanakan shalat fardu lima waktu dengan baik dan benar di kelas VII B MTS NW Karang Baru.

Analisis data dalam penelitian ini dilakukan dengan analisis deskriptif yaitu dengan melihat ketuntasan belajar klasikal. Ketuntasan belajar klasikal dihitung dengan rumus :

$$
\sum \frac{\text { siswa yang tuntas }}{\text { seluruh siswa }} \times 100 \%
$$

Siswa dikatakan tuntas belajarnya secara klasikal, jika mencapai nilai minimal 70

\section{Pembahasan}

\section{Siklus I}

Pada siklus I, guru masuk kelas lalu mengucapkan salam dan mengabsensi kehadiran siswa, guru memberikan apersepsi, guru memberi tahu kepada siswa VII B mengenai adanya kolaborasi guru dengan siswa untuk mengadakan simulasi sholat lima waktu. Kemudian guru menuliskan tujuan pembelajaran, setelah itu membentuk kelompok menjadi 3 kelompok, setelah itu guru memberikan buku kepada masingmasing kelompok untuk membaca bacaan sholat lima waktu dan guru menjelaskan gerakan sholat menggunakan gambar. Lalu guru memanggil 2 orang siswa untuk mensimulasikan sholat lima waktu dan guru mencatat apa-apa yang kurang dalam simulasi sholat lima waktu. Setelah waktu selesai guru mengingatkan siswa yang belum sempurna bacaan dan gerakan sholat agar mempelajari bacaan-bacaan sholat yang sudah guru diberikan kepada masing-masing kelompok dan memperhatikan gerakan sholat yang sudah dijelaskan oleh guru. Tabel 1 menunjukkan hasil alisis data pada siklus I. 
Tabel 1. Daya serap dan ketuntasan klasikal pada siklus 1

\begin{tabular}{lcc}
\hline & Persentase & Jumlah \\
\hline Daya serap & $66,9 \%$ & 24 \\
Ketuntasan klasikal & $32,5 \%$ & 11 \\
\hline
\end{tabular}

Pada tabel 1 diatas terlihat bahwa ketercapaian daya serap siswa mencapai 66,9\% dari 24 siswa dan tingkat ketuntasan klasikal siswa dalam mensimulasikan sholat lima waktu hanya mencapai $32,5 \%$ atau hanya 11 siswa saja yang tuntas. dalam kondisi ini pembelajaran fikih pada kompetensi ini masih belum tuntas.

Pada siklus I membutuhkan waktu yang cukup lama untuk mensimulasikan sholat lima waktu sedangkan mata pelajaran fikih berada di jam terakhir karena pandemi covid 19 waktu pulang dipres sehingga mereka lebih cepat pulang. Walaupun 2 orang siswa yang maju kedepan untuk paraktik itupun menyita waktu yang cukup lama sedangkan waktu pulang lebih cepat serta ada kendala ketika pembelajaran berlangsung. Sehingga siswa banyak yang belum tuntas dalam mensimulasikan sholat dan yang menjadi faktor belum tuntasnya metode simulasi ini dikarenakan jam mata pelajaran fikih berada di jam terakhir pada saat itu siswa sudah mulai lelah dan kurang semangat dalam memperhatikan saat guru menjelaskan. Menyikapi itu semua guru kembali memberikan tugas kepada siswa untuk membaca buku tentang sholat dan menghapalkan bacaan-bacaan dalam sholat serta memperhatikan orang-orang yang sholat kemudian guru merubah sistemnya pada siklus II namun tetap mengguanakan metode simulasi.

Berdasarkan data yang diperoleh maka tampak tingkat ketuntasan siswa masih rendah hanya mencapai $32,5 \%$ atau 11 siswa yang tuntas dengan rata-rata pencapaian target ketuntasan maka peneliti dan kolaborator beranggapan bahwa hasil ketuntasan siswa maka perlu dilanjutkan penelitian pada siklus ke II, peneliti dan kolaborator pada siklus ke II merubah sistemnya namun tetap menggunakan metode simulasi.

\section{Siklus II}

Pada siklus II, guru masuk kelas lalu mengucapkan salam dan mengabsensi kehadiran siswa, guru memberikan apersepsi, guru memberi tahu kepada siswa VII B 
mengenai adanya kolaborasi guru dengan siswa untuk mengadakan simulasi sholat lima waktu. Setelah itu guru melakukan apersepsi dengan menanyakan kembali apa itu sholat, rukun sholat kemudian menjelaskan tentang Kompetensi dasar, Target tata cara sholat yang baik dan benar maka guru menjelasakan pembagian dalam rukun sholat kemudian guru mensimulasikan gerakan sholat yang baik dan benar. Setalah itu mereka membaca kembali bacaan sholat yang belum dihapal, kemudian guru membagi siswa menjadi 3 kelompok dan mempersilahkan masing-masing kelompok maju kedepan untuk mensimulasikan gerakan sholat yang baik dan benar.

Setelah itu guru mempersilahkan siswa secara berpasangan untuk membaca bacan-bacaan dalam sholat, guru dan kolaborator memantau dan melakukan pencatatan terhadap proses KBM, kolaborator siap dengan dokumennya untuk melakukan pencatatan. Tabel 1 menunjukkan hasil alisis data pada siklus 2 .

Tabel 2. Daya serap dan ketuntasan klasikal pada siklus 2

\begin{tabular}{|l|l|l|}
\hline & Persentasi & Jumlah \\
\hline Daya serap & $73,7 \%$ & 24 siswa \\
\hline Ketuntasan klasikal & $71 \%$ & 23 siswa \\
\hline
\end{tabular}

Pada siklus II ketercapaian daya serap siswa mencapai 73,7\% dari 24 siswa dan tingkat ketuntasan klasikal siswa dalam mensimulasikan sholat lima waktu mencapai $71, \%$ atau 23 siswa yang tuntas dalam pembelajaran mata pelajaran fikih. pada mata pelajaran fikih ini sudah mengalami peningkatan walaupun belum mencapai 99,9\%.

Pada siklus II terjadinya peningkatan dalam melaksanakan simulasi sholat fardu lima waktu karena sebelum melakukan simulasi guru menjelasakan pembagian tentang rukun sholat yaitu rukun qolbi (perbuatan hati) rukun dzikri/kauli (perbuatan bibir/berbicara/bacaan) dan rikun fi'li ( perbuatan anggota badan).Untuk rukun dzikrinya guru memerintahkan siswa untuk membaca bacaan sholat yang ada dibuku kemudian untuk rukun fi'li guru menggunakan bantuan gambar serta guru sendiri sebagai media untuk mencohtohkan gerakan-gerakan sholat yang baik dan benar sehingga siswa mudah mengerti. 
Untuk mengefesien waktu satu kelompok maju kedepan untuk mensimulasikan gerakan sholat (rukun fi'li) kemudian untuk rukun dzikri/kauli 2 siswa maju kedepan, namun untuk mengefesien waktu lagi maka 5 orang yang maju kedepan untuk mensimulasikannya. Yang menjadi faktor meningkatnya ketuntansan siswa dalam menggunakan metode simulasi dikarenakan banyak waktu yang tersedia untuk guru menjelaskan secara detail terkait sholat fardu lima waktu dan mensimulasikannya. pada saat itu peneliti meminta izin kepada waka kurikulum untuk mengisi jam kosong sebelum mata pelajaran fikih.

\section{Kesimpulan}

Metode simulasi yang digunakan sudah efektif untuk membantu siswa dalam melaksanakan sholat fardu lima waktu dilihat dari siklus II sudah ada peningkatan dalam pemahaman siswa mengenai tata cara sholat fardu lima waktu dengan baik dan benar dengan persentase daya serap siswa mencapai 73,7\% dan ketuntasan klasikal mencapai $71 \%$ atau 23 siswa yang sudah tuntas. Pada siklus I belum ada peningkatan dengan persentase daya serap masih mencapai 66,9\% dan ketutasan klasikal mencapai 32,5\% atau 11 siswa yang tuntas.Terjadinya perubahan dari siklus I ke siklus II menunjukkan bahwa menggunakan metode simulasi sudah efektif dilakukan.

Penerapan metode simulasi dapat membantu siswa dalam melaksanakan sholat frdu lima waktu karena metode ini sudah efektif, maka sebaiknya metode ini bisa diterapkan dalam mata pelajaran fikih pada sholat fardu lima waktu. Disarankan kepada guru mata pelajaran fikih sejawat agar penelitian ini dilanjutkan dikelas masingmasing dan lebih diekplorasi sehingga metode simulasi lebih efektif lagi untuk membantu siswa dalam melaksanakan sholat fardu lima waktu dengan baik dan benar.

\section{Daftar Refrensi}

Yamin Martinis. Strategi Pembelajaran Berbasis Kompetensi. (Jakarta: Gaung Persada Press, 2007).

http://www.pengertianpakar.com/2014/09/pengertian-fiqih-menurut-para-pakar 
Kementrian Agama Republik Indonesia.2014.buku fikih siswa VII.Jakarta

Sudjana S. Metode Teknik Pembelajaran Partisipatif. (Bandung: Falah Production, 2001).

http://www.infodanpengertian.com/2016/02/pengertian-simulasi-menurut-paraahli.

Suharsimi Arikunto. Prosedur Penelitian Suatu Pendekatan Praktik. (Jakarta: Rineka Cipta, 2013)

E. Mulyasa, Praktik Penelitian Tindakan Kelas. (Bandung : PT. Remaja Rosdakarya, 2009) 